\title{
THE OIL RESOURCES OF TIMOR-LESTE: CURSE OR BLESSING?
}

\author{
Mats Lundahl \\ Fredrik Sjöholm \\ Working Paper 229 \\ October 2006
}

Postal address: P.O. Box 6501, S-113 83 Stockholm, Sweden. Office address: Sveavägen 65

Telephone: +4687369360 Telefax: +468313017 E-mail: japan@hhs.se Internet: http://www.hhs.se/eijs 


\title{
The Oil Resources of Timor-Leste: Curse or Blessing?
}

\author{
Mats Lundahl \\ Fredrik Sjöholm* \\ Stockholm School of Economics
}

\begin{abstract}
Timor-Leste is among the youngest nations in the world. It started its independence under difficult circumstances: poverty is widespread, education is poor, the industrial sector is nonexistent, and political turbulence is on the rise. On the positive side, future oil revenues are predicted to be substantial, which could potentially be of large help in Timor-Leste's strive for development. This paper examines critically the possibility for Timor-Leste to use oil revenues to achieve economic development. It describes how difficult it is to estimate the future revenues because of volatile prices, territorial disputes, and insufficient seismological mapping. It continues with a discussion of the "resource curse": the difficulty of combining natural resources with economic development. Moreover, the particular challenges for Timor Leste's development are dealt with at some length, as are possible ways to avoid the resource curse.
\end{abstract}

JEL Codes: O13; O53; L71

Keywords: Timor-Leste; Oil; Resource Curse; Economic Development

\footnotetext{
${ }^{*}$ Corresponding author. Stockholm School of Economics, P.O. Box 6501, S-113 83 Stockholm, Sweden. Phone

+ 46873693 63. Fax + 4683130 17. Email Fredrik.sjoholm@hhs.se
} 
When Timor-Leste emerged as a sovereign nation in 2002 it was characterized by widespread poverty. The country was one of the poorest both in the East Asian region and in the world (Lundahl and Sjöholm, 2005). The first few years of independence have been characterized by strong efforts to put institutions in place with the help of foreign assistance and by the launching of various programs aiming at poverty reduction. The challenges are considerable and new problems are emerging. An unparalleled and increasing birth rate makes for a population growth so high that it will put considerable strain both on job creation and on the delivery of public services. A very low level of education makes it difficult to expand industrial production simultaneously with the necessary public institutions. Moreover, the political situation in Timor-Leste has recently deteriorated and conflicts have erupted. It seems fair to conclude that such political turbulence is not solely but to a large extent a result of inadequate economic progress (e.g. World Bank, 2006).

The challenges for Timor-Leste are, hence, substantial but they are by no means impossible to meet. The main reason for optimism stems from expected large revenues from oil and gas in the near future. Revenues amounting to several billion US dollars will presumably be collected and invested in a petroleum fund. If properly managed, these revenues will provide a golden opportunity to pursue development oriented policies. The international experience of resource revenue management is, however, not encouraging: most resource rich countries fail to bring about sustained development and remain poor. The reason is a combination of negative economic effects stemming from volatile revenues, decreasing competitiveness of tradable goods, increased corruption and institutional inefficiencies.

The purpose of this paper is to analyze the potential for Timor-Leste to translate large oil and gas revenues into sustained economic development. We start by discussing the magnitude of oil and gas reserves in Timor Leste. This is not a trivial matter considering that political and geographical uncertainties make estimates difficult. More precisely, oil and gas prices are volatile, borders with neighboring countries are unsettled, and seismological explorations remain inadequate. We continue with a discussion of the difficulty of combining oil revenues with development. A number of reasons are identified, such as "Dutch Disease”, volatile public revenues, and rent seeking behavior by domestic actors. The third issue to be discussed is to what extent Timor-Leste can be expected to suffer from these problems. We put special emphasis on the role of US dollar in Timor Leste, the poor level of institutional capacity, and the alleged rise of corruption. We continue with lessons that may be learned from other countries on how to solve the problem of combining oil and development. In 
particular, some relevant lessons from Indonesia are discussed, and so is the newly established oil fund. The paper ends with some concluding remarks.

\section{OIL IN TIMOR-LESTE}

Oil revenues in Timor-Leste are expected be substantial over the next decades. The exact magnitude of these revenues is, however, highly uncertain and estimates have been substantially revised time after time. The uncertainty is twofold. The price of oil is very volatile but it is also uncertain how much oil is found in the territory of Timor-Leste, and how large this territory is. The former issue cannot be solved without more seismological exploration. The second issue, in turn, concerns the controversy with Australia over the sea boundaries.

\section{Volatile Oil Prices}

Figure 1 reports oil prices between April 1985 and January 2006. More precisely, the figures are the daily oil spot prices of North Sea oil (BRENT), the most commonly used measure on world oil prices. ${ }^{1}$ A few conclusions can be drawn from the figure. Firstly, prices on oil are very volatile, ranging from under USD 10 per barrel in July 1986 to around USD 68 in August 2005. The volatility is high even within single years. For instance, prices in 2005 varied between USD 38 and 68, a difference of 78 percent.

\section{Figure 1 about here}

Secondly, the figure seems to suggest that the price trend has been positive since 2002 and that current oil prices are very high in a historical perspective. Any prediction of future oil revenues, however, has to consider the question whether the current high oil price will remain or the volatility will continue with new declines in the price. Some observers suggest that the high oil price is here to stay because of a structural shift in the oil market where too little investment in oil production will lead to a shortage for the foreseeable future. Others argue that the current high price is due to cyclical factors, such as the war in Iraq, the strikes among oil workers in Venezuela in 2002, problems in Nigeria, and an unsustainably high oil demand in China. The proponents of this cyclical explanation of high oil prices believe that prices will

\footnotetext{
${ }^{1}$ The price of BRENT is very similar to the price of West Texas intermediate crude oil (WTI Crude) but differs from the price on oil from the Middle East (Dubai Crude Oil).
} 
soon return to more normal levels. ${ }^{2}$ The different opinions with respect to the causes of high oil prices and their future movement underline the high degree of uncertainty and the difficulties of calculating the value of any oil and gas reserves in Timor-Leste.

\section{Territorial Disputes}

The controversy over the maritime boundary between Timor-Leste and Australia goes back to the colonial days. Indonesia and Australia agreed on a maritime boundary in 1972 based on the principle of 'continental shelf' rather than on the distance between countries (King, 2002, p. 3). More precisely, Australia successfully argued that the Timor Trough was a natural boundary since it separated the continental shelf of Australia from that of Timor (and other parts of Indonesia). Portugal, however, refused to accept this argument and maintained that the natural boundary would be half way between Australia and East Timor. Australia continued to argue that the natural solution would be to draw a straight line between the two ends of the boundary negotiated with Indonesia (see Map 1 in the appendix).

While the maritime border between Australia and Indonesia had been determined both west of the West-East Timor border and east of the island of Timor, no agreement was reached on the portion corresponding to the extension of East Timor itself before the Indonesian occupation. A 'gap' remained on the map, a gap that became known as the Timor Gap (Antunes, 2002, p. 5).

The occupation meant that an agreement on the Timor Gap was to be made between Indonesia and Australia, and negotiations started in 1979. This time, however, Indonesia was not willing to place the boundary in accordance with Australia's argument about continental shelves, mainly because international praxis by then had become less favorable to the Australian argument (Antunes, 2002, p.10). No boundary agreement could therefore be reached and it was instead decided that the disputed area would be a Zone of Cooperation for joint development.

The independence of Timor-Leste has brought the boundary issue up again. As in the previous disputes, the disagreement is whether the boundary should be based on the distance between Timor-Leste and Australia or on the principal of continental shelves. The latter argument seems be weaker today than at the time of the 1972 settlement between Indonesia and Australia. A large number of similar cases around the world have been settled and they seem to support a boundary based on distance (Dusevic, 2004). Also, it has been

\footnotetext{
${ }^{2}$ See Stevens (2005, p. 28) for a discussion on structural and cyclical explanations to the oil price.
} 
questioned whether the division of the continental shelves is really located in the Timor Gap; some reports suggest that the division is actually found north of Timor-Leste (Bugalski, 2004, p. 291). The Australian refusal to let the dispute be solved in the International Court of Justice may be an indication of that Timor-Leste's case is relatively strong (McBeth, 2004b). ${ }^{3}$

Moreover, Timor-Leste is also claiming areas to the east and west of the Zone of Cooperation. The previous boundary takes into account the location of some very small Indonesian islands. This may be against against international law and Timor-Leste has protested against it (Bulgaski, 2004, pp. 291-92).

The Australian dilemma is twofold. An agreement based on the principle of a median boundary between Timor-Leste and Australia would place basically all the oil and gas fields within Timor-Leste’s territory (see Map 2). Also, Australia is afraid that by giving in to Timor-Leste, it will open for Indonesian complaints and renegotiations of the 1972 agreement as well (McBeth, 2004b). ${ }^{4}$

Soon after 1999 it became obvious that the negotiations between Timor-Leste and Australia were going to be difficult and the United Nations Transitional Administration in East Timor (UNTAET) concluded an agreement with Australia that secured the continuation of the work in the Zone of Cooperation, henceforth renamed the Joint Petroleum Development Area (JPDA) (Antunes, 2002, p. 13). The Timor Sea agreement was signed in March 2003. Australia offered Timor-Leste a more favorable agreement whereby the country received 90 percent of the oil revenues compared to the previous Indonesian share of 50 percent (República Democrática de Timor-Leste, 2003). All of the JPDA is north of the median line and, hence, in the area claimed by Timor-Leste.

Australia is continuing to take all, or the bulk of, the revenues from a number of fields that are in the immediate vicinity to the west or the east of the JPDA, such as the Corallina and Laminaria fields to the west and the Sunrise field to the east. Moreover, the country is accused of delaying any settlement and in the meantime exhausting the reserves in areas claimed by Timor-Leste (Gavin, 2004). ${ }^{5}$ Australia is also continuing to issue exploration licenses in the disputed area (Bugalski, 2004, p. 290).

\footnotetext{
${ }^{3}$ Australia withdrew from the section of the International Court of Justice that deals with maritime boundary disputes as late as two months before Timor-Leste’s independence.

${ }^{4}$ It should be noted that the maritime boundary between Indonesia and Timor-Leste also awaits settlement. It seems today that a permanent boundary between these two countries may be affected by the outcome of the negotiations between Australia and Timor-Leste.

${ }^{5}$ For instance, Australia receives revenues of USD 1million per day from the Laminaria-Corallina and Buffalo fields that are now exhausted to at least 75 percent (Bugalski, 2004, p. 293).
} 
A likely future scenario is that Australia and Timor-Leste will separate the financial and the boundary aspects of the dispute and agree on a revenue sharing arrangement in the disputed area and continue with negotiations on the sea boundary.

\section{The Timor-Leste Oil Reserves}

The exact size of the gas and oil reserves of Timor-Leste is not known since the area has been under-explored and all geological reports on Timor-Leste were destroyed in the conflict in 1999 (ESCAP and UNDP, 2003, p. 25). A more careful mapping of Timor-Leste’s natural resources conducted in 2002 suggested that the country possessed rich mineral and hydrocarbon resources (ESCAP and UNDP, 2003). Another major seismic survey was completed in 2005. It indicated that the probability of large endowments of oil and gas was high (Demongeot, 2005).

Map 2 in the Appendix shows some initial estimates of the gas and oil potential of the island of Timor. Most prospects are found in Timor-Leste and relatively few in West Timor. Moreover, it is the south coast and the area in its immediate vicinity that are the most promising areas for gas and oil. No oil and gas deposits have been identified on the north coast of Timor-Leste, and no production has begun anywhere in mainland Timor-Leste.

All of Timor-Leste's oil and gas production presently takes place in the JPDA (see Maps 1 and 3 in the Appendix). Most oil extraction is concentrated to the Bayu Undan field, where production started in April 2004. The field produces around 110,000 barrels of liquids per day. A second phase involving the piping of gas to Darwin is expected to start in 2006 (World Bank, 2005c, p. 3). The gas reserves at Bayu Undan are estimated to be about 400 million barrels of liquids and 3.4 trillion cubic feet of gas (Timor Sea Office, 2006a). These reserves are expected to last for about twenty years and they have an estimated value of USD 6-7 billion (Kyne, 2005).

Elang Kakatua is the only other field presently being developed. It contains relatively small amounts of gas, and is expected to be exhausted in the next few years. The Phoenix field is located next to the Bayu Undan field in the JPDA, but has not yet been developed. It is estimated to contain about 2.3 trillion cubic feet of gas.

The Sunrise field was discovered already in 1974 and is expected to be even larger than the Bayu Undan field. Estimates suggest that it contains about 8.3 trillion cubic feet of gas (three times that of Bayu Undan) and another 200 million barrels of gas (International Monetary Fund, 2005, p.19). The Sunrise field operator, Australia’s Woodside Petroleum, has frozen its activities until an agreement is reached between Australia and 
Timor-Leste with respect to the division of the revenue (Choy, 2005). The problem with the Sunrise field is that it is located both in the JDA and in the disputed sea area. Today, Australia is to receive 82 percent of the revenues from the sunrise field and Timor-Leste 18 percent. The shares were decided in an agreement made in March 2003, but the Timorese government is not pleased with the outcome and wants a larger share. As of early 2006, it seems that negotiations have brought the two countries close to an agreement where each will receive half of the revenues and where the maritime negotiations are deferred for 50 years (e.g. Wilson, 2005). Such an agreement is expected to bring Timor-Leste about USD 13 billion altogether from the Bayu Undan and the Sunrise fields.

Some estimates suggest that Timor-Leste's (unchallenged) part of the Timor Sea may contain half a billion barrels of light oil and some 10 trillion cubic feet of gas (Chua, 2005). Independent contractors will carry out extraction from Timor-Leste’s part of the Timor Sea. The government is presently trying to create an interest in extraction rights among international oil companies. In a first stage, about 30,000 square kilometres between the southern coast of Timor-Leste and the JPDA are to be explored by foreign investors (Chua, 2005). The government is expected to get a substantial share of the revenues: a royalty of 5 percent of gross output, 40 percent of the profits, and a 30 percent tax on profits from the contractor's share (Demongeot, 2005). How attractive these conditions are for the contractors and whether this will result in active participation remains to be seen.

\section{THE RESOURCE CURSE}

Natural resources have sometimes been seen as a curse because of the weak economic performance of many resource rich nations. Countries such as Nigeria, Zambia, and Guyana are relatively resource rich but have also have displayed very slow growth over the last decades and are poor in terms of GDP per capita. In other words, these countries have not been successful in lifting the population out of poverty despite their wealth of resources (Auty, 1993, 2001, Sachs and Warner, 1995, 1999). In addition, resource rich countries tend to have a more unequal income distribution, less democratic regimes, and more corruption (Palley, 2003). These findings might sound surprising but while rich resource endowments were an advantage for industrialization and growth during the nineteenth century, falling transport costs have later reduced this growth effect and such endowments might instead lead to various problems as discussed below.

Countries with rich oil endowments are no exceptions to the resource curse and as a group they have performed economically worse than other countries over the last couple 
of decades (Sachs and Warner, 1995, p. 11). In fact, after some years of rapidly raising incomes, most oil rich countries have seen their per capita incomes fall back to the levels of the 1970s or 1980s (Karl and Gary, 2004, p. 35).

There are several mechanisms behind the observed negative relation between natural resources and economic growth. The World Bank (2005c, p. 304) makes a distinction between two sorts of mechanisms: economic effects and institutional effects. One economic effect is the so-called Dutch Disease: an appreciation of the currency due to increased export revenues from resource export that may shift resources away from sectors with high growth potential to non-tradable sectors with lower growth potential (Corden and Neary, 1982). In an economy that has its own currency this shows up in two different ways. In the first place, the domestic currency will appreciate as foreign currency flows in as a result of oil and gas extraction. The domestic cost level then rises in terms of foreign currency and it becomes harder to export goods and services other than those which led to the original inflow. The inflow of foreign currency also increases the money supply and with that domestic demand and hence the price of non-traded goods. (The price of traded goods, on the other hand, will remain constant since this is determined in the world market.) Production factors are then pulled out of the traded goods sectors and into activities producing non-traded goods.

Moreover, prices of natural resources tend to be volatile, as the example of oil in Figure 1 shows. Volatility has negative effects on economic development. For instance, the boom and bust cycle of resource prices tend to make a country overspend during the boom period, and because of the uncertainties, it also tends to lead to high interest rates, and thereby to less investments in other sectors of the economy (Hausmann and Rigobon, 2002).

Another explanation - perhaps the most important one - is that resource endowments may ruin institutions and increase rent seeking. Firms and individuals become more focused on lobbying for economic rents than to concentrate on efficient use of the resources (Lane and Tornell, 1995). A number of studies have demonstrated that resource rich countries tend to have poor institutions and that these poor institutions explain almost all of the poor growth performance. ${ }^{6}$ One suggested reason is that windfall profits from natural resources tend to corrupt the bureaucracy by shifting its focus away from delivering public services to fighting for control over the rents (Sala-I-Martin and Subramanian, 2003). Some observers claim that oil is related to more corruption than any other line of business, with the exception of arms deals (Gutiérrez, 2003). It should also be noted that even when oil rich

\footnotetext{
${ }^{6}$ See World Bank (2005a, p. 306) for a summary of the literature.
} 
countries attempt to provide e.g. health and education to the population, the results tend to be relatively poor because of the lack of rigor and perseverance in the implementation and the control of costs and outcomes (Karl and Gary, 2004, p. 36).

\section{IS TIMOR-LESTE AT RISK?}

One can of course only speculate about the risk that Timor-Leste will suffer from Dutch Disease, fall into the trap of overspending, or see corruption and inefficient institutions constrain future development. However, poor resource rich countries with poor institutions are the ones most likely to fall into the resource curse trap (Bulte et al., 2005, p. 1039). It therefore seems reasonable to assume that the risk for Timor-Leste is relatively high and that it may be worth while to consider.

The two Dutch disease effects, the appreciation of the currency and the increased price level, are both negative for the non-oil tradable sector. Since the currency of Timor-Leste is the US dollar, however, the former effect disappears. What remains is the latter effect: an increased money supply, increased demand, and higher prices of non-traded goods. The competitiveness of traded goods is eroded when wages and prices on inputs increase but output prices remain at the world level. Alternatively, as in the case of TimorLeste, it becomes difficult for sectors that attempt to establish themselves in the export market to compete for resources. Thus, there is a risk that large oil revenues may act as an obstacle to the development of non-traditional exports and in addition create difficulties for the traditional exports of coffee. This seems to be a real threat, especially when we consider Timor-Leste’s already relatively high prices and wages (Lundahl and Sjöholm, 2006, p.10).

Moreover, one problem with oil extraction is that it is conducive only to relatively weak linkage effects that can be used to encourage the creation of a modern sector in Timor-Leste. In other words, purchases of domestic inputs are very small and relatively few local citizens are employed in the oil sector. The government is trying to persuade the Australian government and the oil field operators that some refineries should be located on the south coast of Timor-Leste. The idea is that these refineries would increase the amount of linkages with the local economy. The distance from Timor-Leste to the oil fields is less than half the distance from Darwin to the fields, which is an argument in favor of a Timor-Leste processing industry. It would mean, however, that the pipeline has to cross the very deep Timor Through, and this may create some technical difficulties. Moreover, whether the government will be successful is highly uncertain, since a pipeline to Darwin is already under construction at a cost of USD 500 million (Timor Sea Office, 2006a). Accordingly, a USD 
one billion processing plant is being set up in Darwin, in addition to already existing plants and infrastructure.

Overspending is perhaps the problem that has been has been most discussed in Timor-Leste. The Timor-Leste government is aware of the uncertainty of future oil revenues and the risk of overspending. This is one of the main reasons why an oil fund has been set up (see the discussion below). It is, however, also widely acknowledged that Timor-Leste has so far avoided the trap and that it is pursuing a prudent macroeconomic policy (e.g. World Bank, 2005b, p. 6).

Finally, it is difficult to predict whether oil revenues will have a negative impact on institutions in Timor-Leste. Institutions are today very weak and many crucial ones, like the judiciary and the Ministry of Finance, are totally dependent on foreign expertise. So the relevant question is not whether windfall revenues will destroy existing institutions but rather if they will become an obstacle to their development.

The main risk is perhaps if bureaucrats are seeking ways of enriching themselves rather than focusing on the provision of public goods. Again, this type of behavior is likely to increase in situations with large inflows of oil revenues. The risks are particularly high in countries, such as Timor-Leste, which are characterized by a lack of an efficient civil service, a legal system, tax authorities, and media (e.g. Karl and Gary, 2004, p. 40). Other high-risk countries are those without democratically accountable leaders, active civil societies and transparent policy processes. Here, Timor-Leste may, however, be performing better than many other oil producing developing countries.

Corruption may have been relatively uncommon during the first few years of independence, at least compared to many other countries in the region. Lately, however, rumors have begun to circulate to the effect that corruption is on the rise. For instance, a World Bank report claims that this is the case and that it may seriously jeopardize the country’s economic development (World Bank, 2005b, p. 5). Some observers also mention that alliances between state and business interests could create another future problem. Finally, it is claimed that border and port officials take bribes to ignore the widespread smuggling of goods from Indonesia, and public officials are said to occasionally accept money in connection with public procurements (e.g. UNOTIL, 2005a, b; Dodd, 2005b).

It is impossible to know exactly how serious the situation is and how much substance there is behind the various types of accusations, but the government must take the potential problems of corruption and its negative effect on institutions seriously. It is therefore positive that former Prime Minister Alkatiri ordered a criminal investigation following a 
report on alleged cases of corruption (Timor Post, 2005). More precisely, the Office of the Inspector General, with the assistance of the United Nations, completed investigations of 66 cases of alleged corruption between 2001 and 2005 (UNMISET, 2005). Five cases were deemed to be criminal acts, including theft, bribery and falsification of official documents. The remaining 61 were considered to be instances of negligence by public officials. Moreover, some ministers often claimed to be involved in corruption were removed in the mid-2005 reshuffle of the government.

However, some observers are more pessimistic and note that none of the cases that have so far been referred by the government for prosecution have proceeded. Moreover, there are allegations that corruption has reached the very core of Timor-Leste's leadership. For instance, three alleged cases of corruption originate in the office of the Prime Minister (Montlake, 2005). Moreover, one of the former Prime Minister's brothers received lucrative ammunition purchasing contracts in a public procurement that has been characterized as nontransparent (Dodd, 2005a). The government, however, argues that the allegations of corruption are highly exaggerated and based on rumors, and that the close monitoring by international organizations provides an effective obstacle to corruption among public officials. $^{7}$

One reason why the court procedure has been slow in the corruption cases is that the judiciary is not functioning in Timor-Leste. All court procedures, not only in corruption cases, are slow. As a result, there is a large backlog of cases to be taken up in court, numbering more than 1,000, with the result that defendants are kept longer in custody than what is legal (Clausen, 2005). There is also a severe lack of qualified personnel in all areas of the judiciary and it is only the presence of foreign experts that enables the system to work even at a rudimentary level. When, recently, an examination of the Timorese judges was undertaken, all of them without exception failed to meet the established standards. The consequence was that all of them had to be removed from their posts and put into full-time training programs. International judges had to be appointed to fill the gaps, but this is of course nothing but a desperate short-run stop-gap measure that will not solve the long-run problem (International Monetary Fund et al., 2005, p.10). A two-and-a-half-year training program for local judges has been initiated and financed by Portugal. However, the program is in Portuguese, a language that few of the judges understand (Clausen, 2005). It should also be noted that there are allegations of corruption even in the judiciary. For instance, a number

\footnotetext{
${ }^{7}$ See e.g. the comments by present Prime Minister José Ramos Horta in McKenna (2005).
} 
of prosecutors are under investigation for taking bribes, often in order to drop charges (UNOTIL, 2005c). It thus seems likely that it will take considerable time before the judiciary will work efficiently and without the help of foreign experts.

\section{Learning from the Occupant}

One should not let the above description of potential risks with rich endowments of natural resources obscure the fact that Timor-Leste would be in a worse position without these endowments. Compared to most countries at a similar development level, the oil and gas revenues of Timor-Leste bring the opportunity to make valuable investments in, for instance, infrastructure, education and health. It also means that Timor-Leste has no public debt and that it enjoys a budget surplus, two economic features that are uncommon in developing countries.

It should also be mentioned that there are countries that have been successful in combining large revenues from natural resources with high and sustainable economic growth and social development. Interestingly, one of the prime examples is Timor-Leste's former occupant, Indonesia (World Bank, 2005d, pp. 306-07).

Indonesia is Southeast Asia's largest oil producer and the country faced dramatically increased revenues after the oil boom in 1974. For instance, oil revenues as a share of total government revenues increased from 21 percent in 1971 to 48 percent in 1974 and a peak of 62 percent in 1981 (Hill, 1996, p. 46). The government revenue from oil came mainly from taxes on foreign oil producers operating in Indonesia (Thee, 2002, p. 207).

The oil boom years were characterized by very high economic growth: GDP growth between 1973 and 1981 averaged 7.5 percent annually, a rate that has only been surpassed in Indonesia in the late 1960s and early 1970s (Hill, 1996, p. 21). The high growth was accompanied by low inflation and prudent fiscal policies. Herein lies one explanation of the successful Indonesian development. The government managed to balance the large inflows of oil revenues by pursuing a prudent macroeconomic policy and it did not fall into the trap of overspending (Usui, 1997).

Moreover, Indonesian economic growth was fueled by a strong expansion of agriculture and manufacturing. ${ }^{8}$ This was an outcome of the explicit Indonesian strategy of using oil revenues to improve the competitiveness of the tradable sectors. For instance, considerable resources were put into agriculture to boost rice production. Emphasis was put

\footnotetext{
${ }^{8}$ Manufacturing accounted for about 22 percent of total GDP growth during the oil boom, followed by trade with 17 percent, agriculture with 16 percent, and public administration with 13 percent (see Hill, 1996, Table 2.1).
} 
on the use of high-yield rice varieties, fertilizers, and irrigation, with the result that Indonesia became self-sufficient in rice production by the mid-1980s (Booth, 1988).

The growth of industry and agriculture was also supported by currency devaluations in the 1970s and 1980s that partly offset the appreciation of the real exchange rate caused by large oil revenues (Usui, 1997, p. 158). Hence, Indonesia avoided a Dutch Disease that leads to decreasing competitiveness of the country's tradable sectors.

One positive result of the Indonesian government's attempt to diversify the economy was that the drop in oil prices and oil revenues in the early 1980s could be balanced by a steady growth in agriculture, and by a subsequent strong expansion of manufacturing (Tabor, 1992, p.161; Hill, 1996, Ch. 7-8).

The government also pursued policies that made large shares of the population benefit from the increased revenues. For instance, efforts were made to expand the provision of health and basic education after the oil boom (Sjöholm, 2005, p. 43; Thee, 2002, p. 203). Moreover, substantial resources where used in infrastructure projects in more backward parts of the archipelago through the Inpres program (Sjöholm, 2002, p. 384). ${ }^{9}$

An interesting question is why Indonesia succeeded in pursuing a sound economic policy when so many other resource rich countries failed. Perhaps the most important reason is the strong and unique role of economists or 'technocrats' in Indonesian policy making since the launch of the 'New Order' in 1966. The economy was close to a collapse during the last years of the Sukarno regime in the early 1960s, and substantial policy changes were needed to turn the deteriorating situation around. When President Suharto took over power in 1966, he relied to a large extent on advice from a group of economists sometimes referred to as the 'Berkeley Mafia' because several of its members had pursued post-graduate studies at University of California, Berkeley - in the formulation of a new set of economic policies (Thee, 2002, pp. 194-96). Unfortunately, the reason why the technocrats got such a strong role in the policy process seems to have a lot to do with the specific context of Suharto's Indonesia at the time and may therefore be difficult to use as guidelines for other countries.

While it is difficult to use the Indonesian example to prescribe direct policies for Timor-Leste, there are nevertheless a few aspects worth considering. First, it is of utmost importance that increased oil revenues are accompanied by a sound macroeconomic policy. Second, oil revenues bring an opportunity to improve the competitiveness of tradable sectors

\footnotetext{
${ }^{9}$ Inpres - Instruksi Presiden (Presidential Instruction).
} 
and social development. In particular, it would be wise to follow the Indonesian example of channelling resources to the agriculture sector, considering the importance of agriculture for the overwhelming majority of the population of Timor-Leste.

\section{THE PETROLEUM FUND}

It is clear that Timor-Leste will be in a fortunate position with large increases in government revenues and large budget surpluses over the coming years. The discussion above also suggests that there is a serious risk that the large oil revenues will cause economic problems for the country, if not dealt with properly. Again, the main risks are that the volatility of the oil incomes will make it difficult to make long-term plans, and that windfall gains will increase corruption and bureaucratic inefficiency. In addition, we have also discussed the weak institutional capacity in Timor-Leste. One sign of this problem is that the budget implementation is running behind schedule, even in a situation with relatively modest expenditures (Lundahl and Sjöholm, 2005, p. 31). The main reason for lagging expenditures is that there is a lack of administrative capacity to increase government spending. Together with the general weak level of development, this means that the capacity to spend large and increasing amounts of oil revenues in an efficient way is seriously constrained.

One approach to the spending bottleneck is to save the oil revenues and not use more than what can be efficiently spent. The government of Timor-Leste will pursue such a policy and has created a petroleum fund. The fund has been set up with the Norwegian oil fund as a model, and Norwegian advisers have been providing the necessary knowledge. In addition, the regulatory framework around the petroleum fund is explicitly addressing transparency and accountability issues, which the Norwegian oil fund does not, and it is therefore sometimes referred to as the "Norway Plus Model” (Drysdale, 2005). The Ministry of Planning and Finance will be responsible for the fund and the operational management will be entrusted to the Central Bank. A special steering committee will be set up to advice the ministry, and auditing will be performed by an independent, external, agency.

The basic idea behind the fund is to guarantee that the expected oil revenues over the next 20-30 years are spent wisely, in the interest of the economic development of the country (Ministry of Planning and Finance, 2004). To ensure intergenerational equity, the fund builds on the perpetual income concept, i.e. in the longer run the real value of petroleum wealth should be kept constant over time. The permanent income of the fund will be spent each year, and anything in excess of that will be added to the fund. More precisely, only the interest component on the sum of current assets and expected future revenues is spent every 
year. In Timor-Leste this is referred to as the Estimated Sustainable Income (ESI), to be revised annually. The ESI is the maximum amount that can be spent. It is likely that the capacity to spend will be low, below the ESI, in the immediate future, which means that the difference will remain in the fund and increase the ESI in coming years.

The Petroleum Fund law was approved by Parliament on 27 June 2005. This law is the basic tool for managing the oil fund (Drysdale, 2005, p.2). It provides guidelines for how much of the fund should be withdrawn and how the revenues should be invested. It also establishes penalties for any mismanagement of the fund and provides instructions for the establishment of a consultative council (Democratic Republic of Timor-Leste, 2005a). Other parts of the regulatory framework include the Petroleum Act and the Petroleum Tax Law from July 2005.

The Petroleum Fund Law states that all income from oil, including profits, royalties and taxes, should be invested in the fund. Moreover, the fund should be invested abroad in low-risk financial assets and the returns on these assets are to be reinvested in the fund. The reason for the latter requirement is the desire to put less pressure on the domestic economy and reduce the risk of corruption and bad governance. Transfers from the fund have to be approved by Parliament and can only be spent via the government budget (Drysdale, 2005, p. 3).

It is difficult to estimate how large the petroleum fund will be, and hence how large withdrawals it will allow. Oil and gas revenue is presently projected to rise until reaching a peak in 2011 and then fall off towards eventual exhaustion in the mid-2020s. The projections are, however, uncertain, with respect to both timing and magnitude (Cotton, 2005, pp. 188-90). As previously discussed, the exact size of the reserves is not known and the maritime boundary between Timor-Leste and Australia has not yet been determined. Most importantly, the present forecasts only include potential revenues from currently exploited fields. Hence, the extraction from new fields, which are very likely to be in operation in a few years' time, are not included, meaning that the forecasts are conservative. More precisely, it is estimated that Timor-Leste will receive revenues of around USD 5 billion given the present maritime boundaries with Australia but almost three times as much under a settlement that is favourable to Timor-Leste’s boundary claims (Timor Sea Office, 2006b).

Moreover, the pace and cost of extraction remain uncertain and the oil price will also have a large effect on the size of the petroleum fund. As an example, forecasts made in 2004 showed expected oil revenues of around USD 3.7 billion. However, with a price that is USD 5 lower per barrel the figure shrinks to some 2 billion, and with a USD 5 higher price, it 
increases to 5 billion (Ministry of Planning and Finance, 2004, p. 7). The base scenario is rather conservative with a predicted oil price which is not only USD 5 lower than the NYMEX figures but also discounted by an additional 15 percent.

Given the qualifications above it should be clear that the predicted ESI is likely to change substantially over the years. In our opinion, it is likely to increase rather than decline. The net present value of oil and gas revenues from the two existing fields is estimated to about USD 3.2 billion. To put the figure in perspective, this is more than nine times TimorLeste’s 2004 non-oil GDP (International Monetary Fund, 2005, p.16). In the public budget for 2004/05 the size of the ESI is given as USD 100 million (Democratic Republic of TimorLeste, 2005b). Hence, the prediction is that the government can spend USD 100 million from the petroleum fund from this budget year to eternity. Other projected domestic revenues are estimated at about USD 30 million per annum over the next few years. Hence, oil revenues will constitute a substantial share of the total budget revenues and the government plans to spend less than this amount during the coming years.

Given the large assets in the fund and the poor level of development in TimorLeste, it will be tempting for any future government to increase withdrawals. It is also likely that the risk of such behavior increases with the political turbulence that seems to be on the rise in Timor Leste. As previously stated, such measures require approval by the Parliament but this arrangement is of course no guarantee against future misuse of the fund. Countries such as Oman and Venezuela also have similar types of stabilization funds and have made frequent changes of the rules, with negative effects on the economy (International Monetary Fund, 2005, p.22).

\section{CONCLUDING REMARKS}

Timor-Leste began its independence as one of the poorest nations in the world. Substantial progress has been made thereafter but the challenges for future development are numerous. Still, Timor-Leste is relatively fortunate. Compared to many other countries on a similar income level it receives large international assistance, it has no public debt, and it is running a budget surplus. The large inflow of oil and gas revenues provides a unique opportunity to bring the country out of poverty.

It should be noted, however, that economic development will not be automatic. It requires careful and stringent policies. If not, the black gold might turn out to be the 
excrement of the devil. ${ }^{10}$ The main risk with large windfall gains from resources such as oil and gas is that the government may start to overspend, that income volatility and Dutch Disease wipe out the tradable sector and that corruption ruins institutions and the social fabric of a country. The government is clearly aware of the danger and has established a petroleum fund aimed at the generation of a perpetual and manageable income stream. Whether this measure will be sufficient to avoid the resource curse, however, remains to be seen.

${ }^{10}$ The Venezuelan minister Juan Pablo Pérez Alfonso, quoted in Karl (2003), p. 8. 


\section{REFERENCES}

Antunes, Nuno Sérgio Marques (2002), 'Spatial Allocation of Continental Shelf Rights in the Timor Sea: Reflections on Maritime Delimitation and Joint Development', Timor Sea Office, http://www.timorseaoffice.gov.tp/nunoarticle13-13.pdf

Auty, Richard M. (1993), The Resource Curse Thesis. London and New York: Routledge

Auty, Richard M. (ed.) (2001), Resource Abundance and Economic Development. Oxford: Oxford University Press

Booth, Anne (1988), Agricultural Development in Indonesia. Sydney: Allen and Unwin

Bugalski, Natalie (2004), 'Beneath the Sea: Determining a Maritime Boundary Between Australia and East Timor’, Alternative Law Journal, Vol. 29: 289-298

Bulte, Erwin H., Damania, Richard and Deacon, Robert T. (2005), 'Resource Intensity, Institutions, and Development', World Development, Vol. 33: 1029-1044

Choy, Marguerita (2005), 'Australia Expects East Timor Gas Pact in Months’, Reuters, 13 September

Chua, Chin Chye (2005), 'Timor Leste Seeks Bids for Oil, Gas Exploration', Channel News Asia, 7 October

Clausen, Lisa (2005), 'East Timor Judges Fail Their Test', Time Asia, 14 February

Corden, W. Max and Neary, J. Peter (1982), 'Booming Sector and De-Industrialisation in a Small Open Economy’, Economic Journal, Vol. 92: 825-848

Cotton, James (2005), 'East Timor in 2004: It Is All about the Oil', Asian Survey, Vol. 45: 186-190.

Democratic Republic of Timor Leste (2005a), The Petroleum Fund Law, Dili. 
Democratic Republic of Timor Leste (2005b), General Budget of the State 2005-06, Dili.

Dodd, Mark (2005a), 'East Timor Democracy in Danger as Graft and Poverty Spread', The Australian, 26 July

Dodd, Mark (2005b), ‘Timor Leader “Furious’ Over Corruption Report’, The Australian, 27 July

Demongeot, Maryelle (2005), 'East Timor Offers 15 Oil, Gas Blocks in Upstream Launch', Reuters, 2 September

Drysdale, Jennifer (2005), Managing Petroleum Revenue in Timor-Leste: A Brief Explanation', Development Bulletin, No. 68, Canberra: Australia National University

Dusevic, Tom (2004), ‘Hands Off My Petroleum!’, Times Magazine, 10 May

ESCAP and UNDP (United Nations Economic and Social Commission for Asia and the Pacific and United Nations Development Programme) (2003), Exploring Timor-Leste: Mineral and Hydrocarbon Potential, New York: United Nations

Gavin, James (2004), ‘Timor Sea: Messy Politics’, The Petroleum Economist, March

Gutierrez, Miren (2003), 'Corruption: Murky Business in Oil’, International Press Service, 20 August

Hausmann, R. and Rigobon, R. (2002), 'An Alternative Interpretation of the "Resource Curse”: Theory and Policy Implications’, NBER Working Paper No. 9424, National Bureau of Economic Research, Cambridge, Mass

Hill, Hal (1996), The Indonesian Economy Since 1966. Cambridge: Cambridge University Press 
International Monetary Fund (2005), 'Democratic Republic of Timor-Leste: Selected Issues and Statistical Appendix', Washington DC: IMF

International Monetary Fund and International Development Association (2005), 'Joint Staff Advisory Note on the Poverty Reduction Strategy Paper', http://siteresources.worldbank.org/ INTPRS1/Resources/Timore-Leste_JSAN(April29-2005).pdf

Karl, Terry Lynn (2003), ‘The Oil Trap’, Transparency International’s Quarterly Newsletter, September

Karl, Terry Lynn and Gary, Ian (2004), Oil and Development: The Global Record. Washington DC: Institute for Policy Studies

King, Robert J. (2002), 'The Timor Gap, Wonosobo and the Fate of Portuguese Timor', Journal of Royal Australian Historical Society, Vol. 88: 1-20

Kyne, Phelim (2005), 'Interview: East Timor PM Sees Intl Bank Role in Oil Fund', Dow Jones Newswires, June 23, 2005. http://www.transparency.gov.tl/Record/AP\%20Thursday\% 20June\% 2023. doc

Lane, Philip R. and Tornell, Aaron. (1995), 'Power Concentration and Growth', Harvard Institute of Economic Research Discussion Paper No. 1720

Lundahl, Mats and Sjöholm, Fredrik (2005), 'Poverty and Development in Timor-Leste', Sida Country Economic Report 2005:3, Stockholm: Sida

Lundahl, Mats and Sjöholm, Fredrik (2006), 'Population and Job Creation in Timor-Leste', Stockholm School of Economics, EIJS Working Paper No. 226

McBeth, John (2004a), ‘Oil Futures’, Far Eastern Economic Review, 17 June McBeth, John (2004b), 'Canberra’s Sea of Troubles’, Far Eastern Economic Review, 8 July 
McKenna, Michael (2005), 'Corruption Not So Rife: Ramos Horta', The Australian, 16 August

Ministry of Planning and Finance (2004), Establishing a Petroleum Fund for Timor-Leste. Public Consultation Discussion Paper, October. Dili

Montlake, Simon (2005), 'Young Nation Wrestles With Its “Black Gold”', South China Morning Post, 30 August

Palley, Thomas I. (2003), 'Lifting the Natural Resource Curse’, Foreign Service Journal, Vol. 80: 54-61.

República Democrática de Timor Leste (2003), Law No. 3/2003 of 1 July: Taxation of BayuUndan Contractors Act. http://www.transparency.gov.tl/PA/tbuca_eng.pdf

Sachs, Jeffrey D. and Warner, Andrew M. (1995), 'Natural Resource Abundance and Economic Growth’, NBER Working Paper No. 5398, National Bureau of Economic Research, Cambridge, Mass

Sachs, Jeffrey D. and Warner, Andrew M. (1995), 'The Big Push, Natural Resource Booms and Growth', Journal of Development Economics, Vol. 59: 43-76

Sala-I-Martin, X. and Subramanian, A. (2003), 'Addressing the Natural Resource Curse: an Illustration from Nigeria', IMF Working Paper 03/139, Washington DC: International Monetary Fund

Sjöholm, Fredrik (2002), 'The Challenge of FDI and Regional Development in Indonesia', Journal of Contemporary Asia, Vol. 32: 381-393

Sjöholm, Fredrik (2005), 'Educational Reforms and Challenges in Southeast Asia', in Fredrik Sjöholm and Jose Tongzon (eds.), Institutional Change in Southeast Asia. Routledge

Stevens, Paul (2005), ‘Oil Markets’, Oxford Review of Economic Policy, Vol. 21:19-42. 
Tabor, Steven R. (1992), ‘Agriculture in Transition’, in Anne Booth (ed.), The Oil Boom and After: Indonesian Economic Policy and Performance in the Soeharto Era. Oxford: Oxford University Press

Thee, Kian Wie (2002), 'The Soeharto Era and After: Stability, Development and Crisis, 1966-2000’, in Howard Dick, Vincent J.H. Houben, J. Thomas Lindblad, and Thee Kian Wie, The Emergence of a National Economy: An Economic History of Indonesia, 1800-2000. Allen \& Unwin and University of Hawaii Press

Timor Post (2005), 'Bianco: The Prime Minister had Raised the Corruption Issue', downloaded January 3, 2006 from

http://www.unmiset.org/UNMISETWebSite.nsf/0/084598b273d580bd492570840029d9d2?O penDocument

Timor Sea Office (2006a), 'The Bayu-Undan Development’, downloaded 9 January, 2006 from http://www.timorseaoffice.gov.tp/bayufacts.htm

Timor Sea Office (2006b), 'Revenue Management', downloaded 9 January, 2006 from http://www.timorseaoffice.gov.tp/revmngtfacts.htm

UNMISET (United Nations Mission of Support in East Timor) (2005), 'UNOTIL Plans to Increase Assistance to Timor-Leste to Combat Corruption’, downloaded 3 January, 2006 from http://www.unmiset.org/UNMISETWebSite.nsf/60325cf12626b2a349256f0a003ef7d8/b70bb 3faca1d83814925703b00305cbb?OpenDocument

UNOTIL (United Nations Office in Timor-Leste) (2005a), 'MH Bribery Case to be Sent to Court', East Timor Daily Media Review, 14 June

UNOTIL (United Nations Office in Timor-Leste) (2005b), 'BPU Suspected of Receiving Bribes’, East Timor Daily Media Review, 1 August

UNOTIL (United Nations Office in Timor-Leste) (2005c), ‘3 Timorese Prosecutors Accused of Corruption', East Timor Daily Media Review, 25 August 
Usui, Norio (1997), 'Dutch Disease and Policy Adjustments to the Oil Boom: a Comparative Study of Indonesia and Mexico’, Resources Policy, Vol. 23:151-162

Wilson, Nigel (2005), 'Agreement Close on East Timor Revenue', The Australian, 6 September

World Bank (2005a), World Bank Country Assistance Strategy for Timor-Leste FY 06-08. Creating the Conditions for Sustainable Growth and Poverty Reduction. Report No. 32700TP. 11 August. Washington, D.C.: World Bank

World Bank (2005b), 'Program Document', Report No.32868-TP, Washington, D.C.: World Bank.

World Bank (2005c), Economic Growth in the 1990s: Learning from a Decade of Reform, Washington, D.C.: The World Bank

World Bank (2006), Timor-Leste Crisis 2006, Dili: The World Bank. Downloaded 18 September 2006 from

http://web.worldbank.org/WBSITE/EXTERNAL/COUNTRIES/EASTASIAPACIFICEXT/TI MORLESTEEXTN/0,,menuPK:294031 pagePK:141132 piPK:141107 theSitePK:294022,0 $\underline{0 . h t m l}$ 


\section{Appendix ${ }^{11}$}

\section{Map 1.}

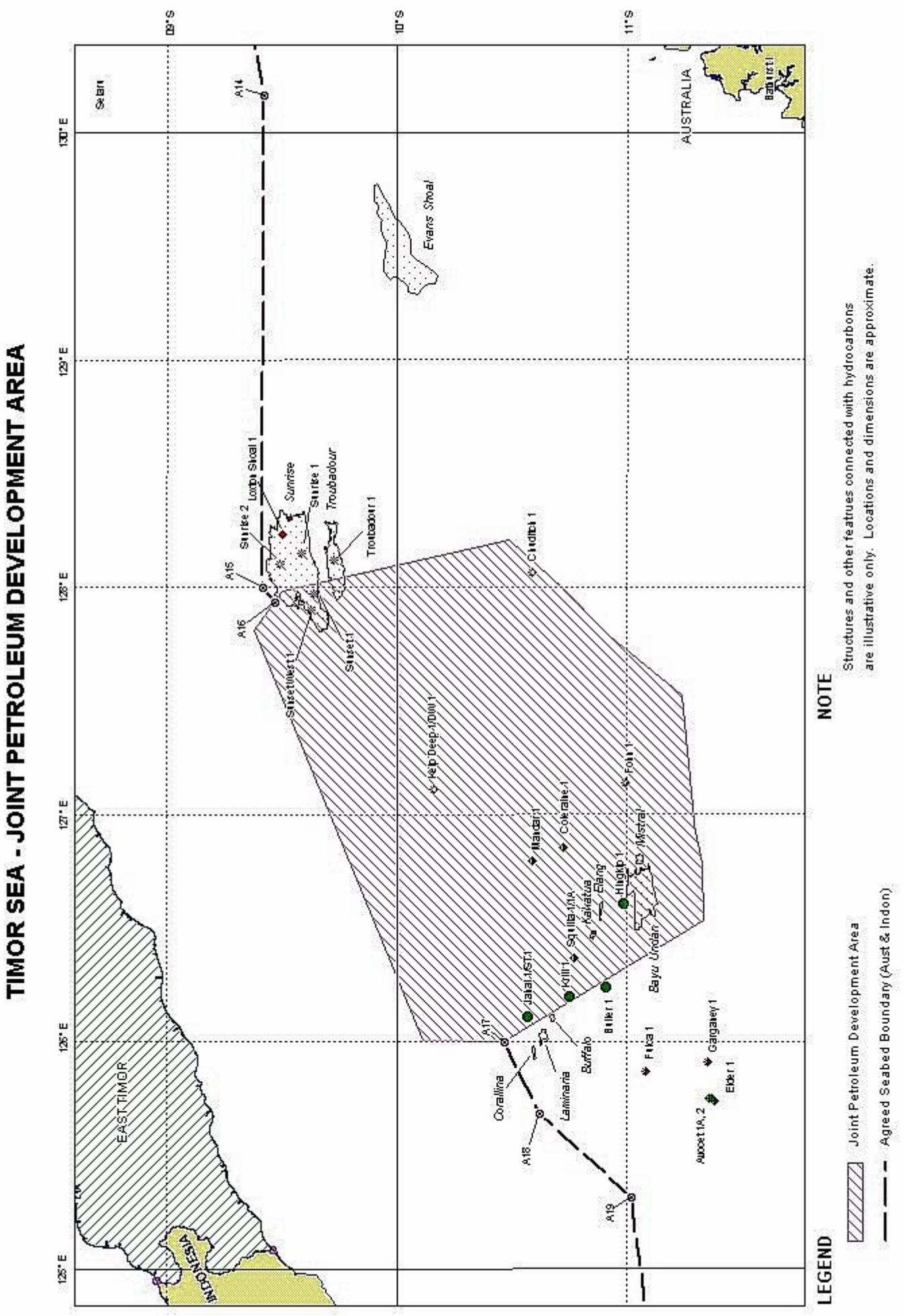

\footnotetext{
${ }^{11}$ All the maps have been obtained from the Timor Sea Office in Dili.
} 


\section{Map 2.}

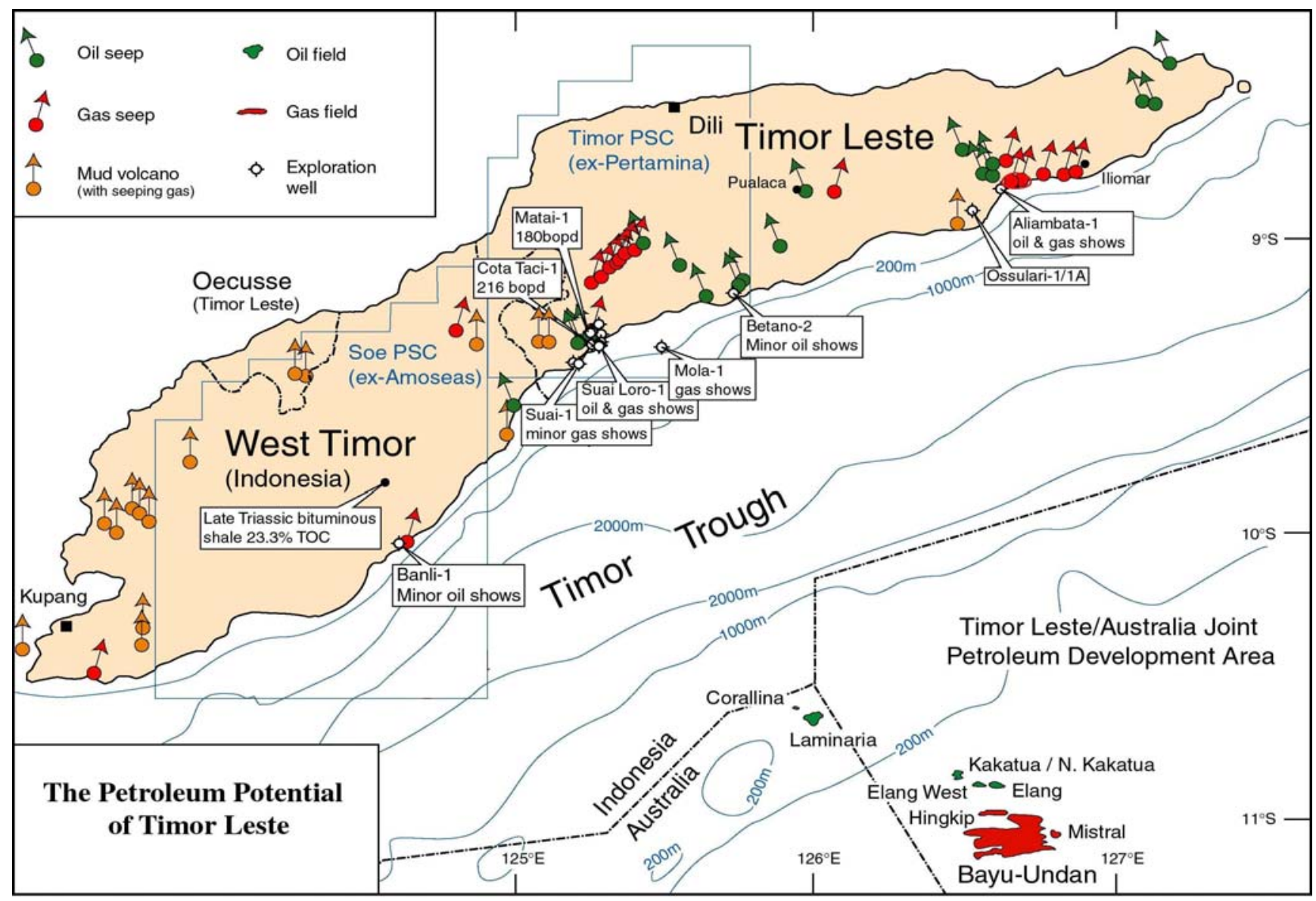


Map 3.

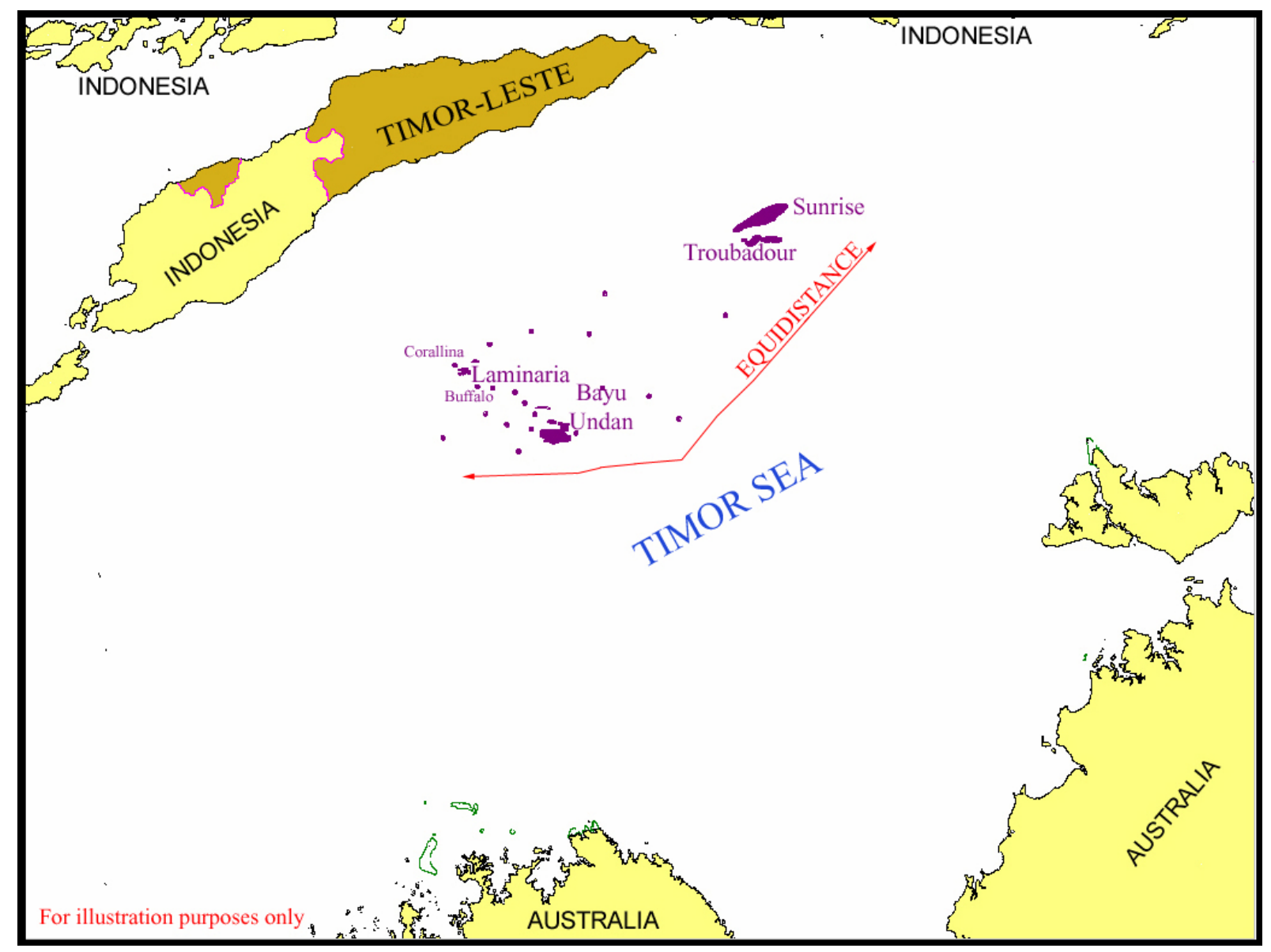




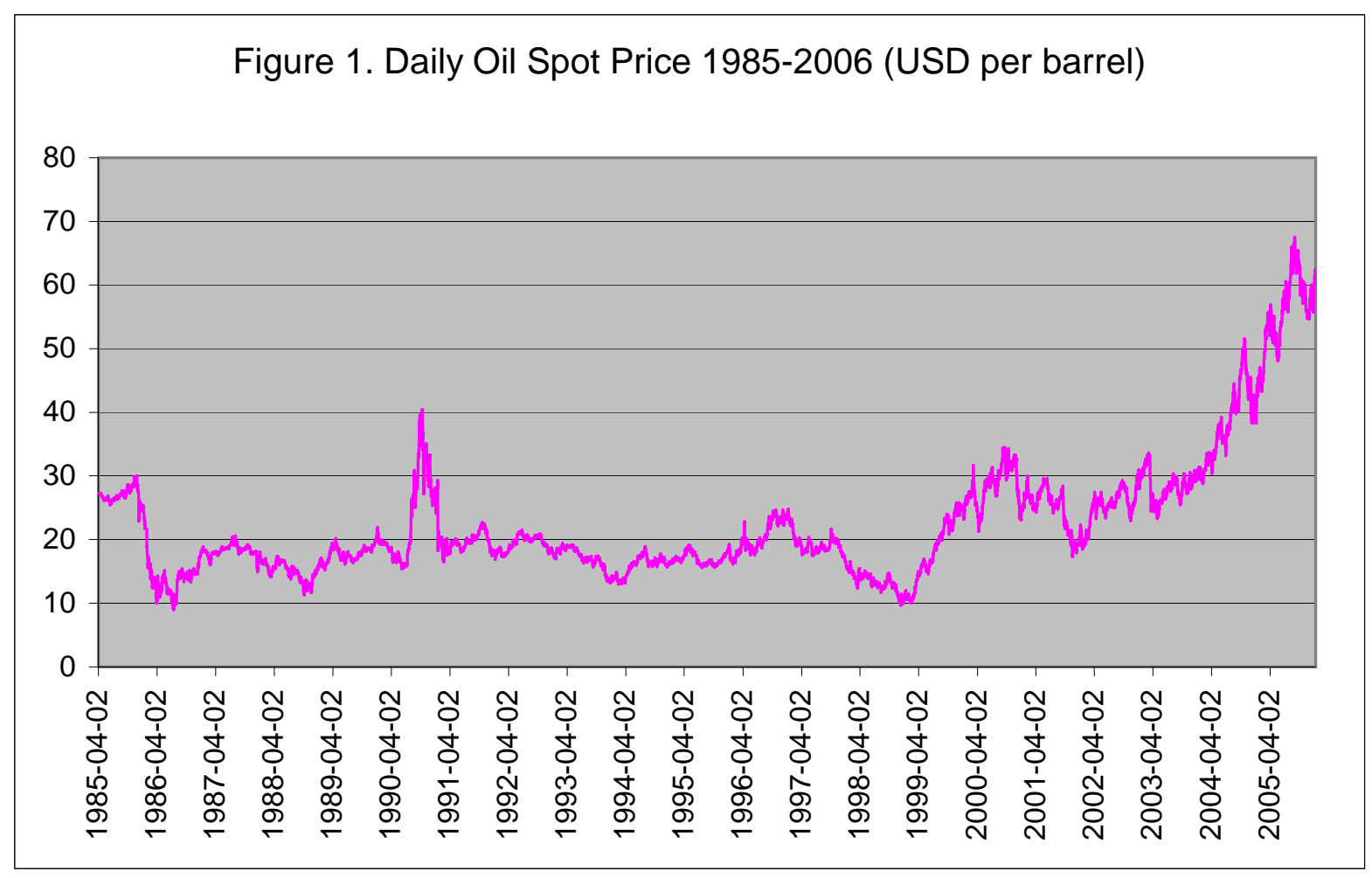

Source: DataStream. 